\title{
SECOND RECORD OF Lasiurus ega (GERVAIS) (MAMMALIA, CHIROPTERA, VESPERTILIONIDAE) OVER THE SOUTH ATLANTIC
}

\author{
ESBÉRARD, C. E. L. ${ }^{1}$ and MOREIRA, S. C. ${ }^{2}$ \\ ${ }^{1}$ Departamento de Ecologia, IBRAG, Universidade do Estado do Rio de Janeiro, \\ Rua São Francisco Xavier, 524, CEP 20559-900, Rio de Janeiro, RJ, Brasil \\ ${ }^{2}$ Everest Tecnologia em Serviços Ltda., Av. Nossa Senhora Navegantes, 671/1201, CEP 29056-900, Vitória, ES \\ Correspondence to: Carlos Eduardo Lustosa Esbérard, Departamento de Ecologia, IBRAG, Universidade do Estado do Rio \\ de Janeiro, Rua São Francisco Xavier, 524, CEP 20559-900, Rio de Janeiro, RJ, Brasil, e-mail: cesberard@ terra.com.br \\ Received November 8, 2004 - Accepted December 27, 2004 - Distributed February 28, 2006
}

(With 1 figure)

Lasiurus ega (Gervais, 1856) occurs from the southwestern United States to northern Argentina and Uruguay, with the most austral record being Buenos Aires province, Argentina, at $40^{\circ} \mathrm{S}$ (Baker et al., 1971; Barquez et al., 1993; Eisenberg, 1989; Redford \& Eisenberg, 1992). This species was recorded over the open south Atlantic Ocean on March 15, 1960, $335 \mathrm{Km}$ from the cost of Argentina (Van Deusen, 1961). Lasiurus ega most often roosts in trees, generally hanging by its feet from the midrib of a leaf and occasionally by its thumbs as well (Nowak, 1994). This species commonly roosts among dead fronds of palm trees and the use of ornamental palms in the southwestern United States may have helped the bat to extend its range northward (Spencer et al., 1988).

On April 9, 2002, an adult male with a forearm length of $47.05 \mathrm{~mm}$ and weighing $11.2 \mathrm{~g}$ landed at night on the seismic vessel Ramform Explorer, which was on the open seas $145 \mathrm{Km}$ from Brazil's southeastern coast (Fig. 1).

Both Lasiurus borealis (Muller, 1776) and L. cinereus (Beauvois, 1796) are migratory, moving southward during the fall, and eventually landing on ships or oceanic islands (Baker, 1956; Findley et al., 1975; Griffin, 1940; Nowak, 1994). Populations of Lasiurus seminolus (Rhoads, 1895) can move south or enter torpor in colder months (Barbour \& Davis, 1969). In the northern hemisphere, males of $L$. ega become scarce between April and June, while females are present yearround, suggesting a migratory strategy (see Kurta \& Lehr, 1995). Lasiurus ega shows a tendency to migrate toward the Equator, as described for other species of the genus (Kurta \& Lehr, 1995).

Bats that migrate along coastlines take shortcuts over water. Many North American migrant bats can be found at a distance of several kilometers from their normal destination during fall and spring migrations, probably having been blown there by wind (Constantine, 2003). Both records of L. ega in the Southern Hemisphere indicate movements at the end of summer and beginning of fall, supporting the theory that at least some animals migrate to avoid cold temperatures. With this second sighting, the probability that both records of this species over the South Atlantic were the result of wind has become less likely. 


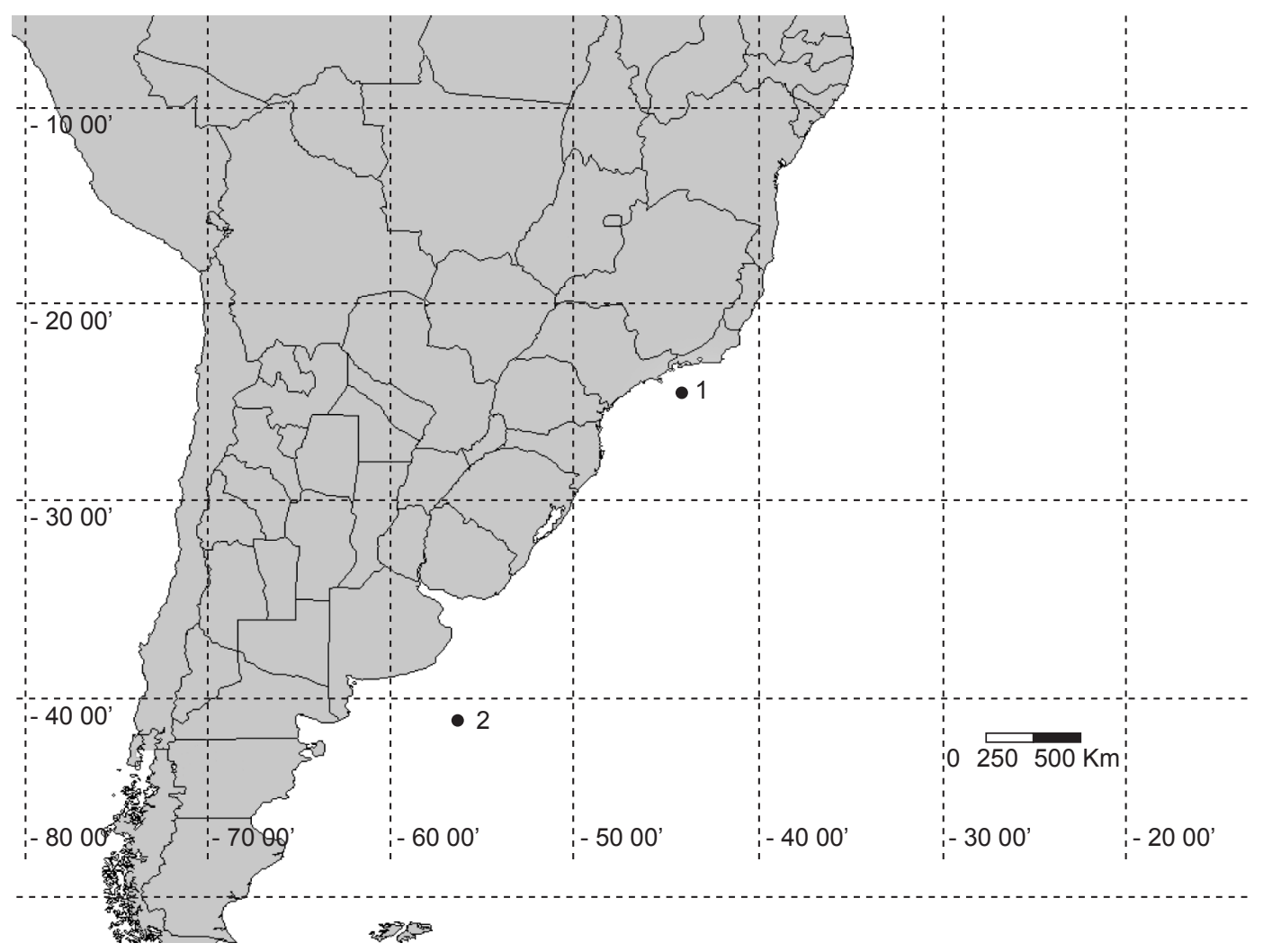

Fig. 1 - Two oceanic records of Lasiurus ega in South America: 1) Present work; and 2) Van Deusen (1961).

Acknowledgments - The bat is deposited as a voucher in the reference collection of the Projeto Morcegos Urbanos (License Process 1456/95-46 Ac-SUPES/DF/IBAMA) and is identified with the number PMU3555. We are indebted to Everest Tecnologia em Serviços Ltda and PGS Investigação Petrolífera Ltda for welcoming Brazilian researchers aboard their vessels and for encouraging the scientific publication of the data collected. We wish to thank Tatiana Fernandes reviewing this manuscript. Carlos E. L. Esbérard received a grant (151029/2004-0) from CNPq (Brazil).

\section{REFERENCES}

BAKER, R. J., 1956, Mammals of Coahuila, Mexico. University of Kansas Publications. Museum of Natural History, 9: $125-335$

BAKER, R. J., MOLLHAGEN, T. \& LOPEZ, G., 1971, Notes on Lasiurus ega. Journal of Mammalogy, 48: 270-286.

BARBOUR, R. W. \& DAVIS, W. H., 1969, The University of Kentucky. Bats of America. Lexington, Kentucky, 286p.

BARQUEZ, R. M., GIANNINI, N. P. \& MARES, M. A., 1993, Oklahoma Museum of natural History. Guide to the bats of Argentina. University of Oklahoma, Norman, 119p.

CONSTANTINE, D. G., 2003, Geographic translocation of bats: known and potential problems. Emerging Infectious Diseases, 9: 17-21.
EISENBERG, J. F., 1989, Mammals of the Neotropics. The northern neotropics. Panama, Colombia, Venezuela, Guyana, Suriname, French Guiana. The University of Chicago Press, Chicago, $1^{\circ}$ vol., 439p.

FINDLEY, J. S., HARRIS, A. H., WILSON, D. E. \& JONES, C. 1975, Mammals of New Mexico. University of New Mexico Press, Albuquerque, New Mexico, 360p.

GRIFFIN, D. R., 1940, Migrations of New England bats. Bulletin of the Museum of Comparative Zoology at Harvard College, 76: 217-46.

KURTA, A. \& LEHR, G. C., 1995, Lasiurus ega. Mammalian Species, 515: 1-7.

NOWAK, R. M., 1994, Walker's bats of the world. The John Hopkins University Press, Baltimore, 283p.

REDFORD, K. H. \& EISENBERG, J. F., 1992, Mammals of the Neotropics. The Southern Cone. Chile, Argentina, Uruguay. The University of Chicago Press. Chicago, $2^{\text {nd }}$ vol., 430p.

SPENCER, S. G., CHOUCAIR, P. C. \& CHAPMAN, B. R., 1988, Nortward expansion of the southern yellow bat, Lasiurus ega, in Texas. The Southwestern Naturalist 33: 493.

VAN DEUSEN, H. M., 1961, Yellow bat collected over South Atlantic. Journal of Mammalogy, 42: 530-531. 